\title{
Problematika Proses Pembelajaran Pendidikan Agama Islam
}

\author{
Tasurun Amma ${ }^{1 *}$ \\ ${ }^{1}$ Sekolah Tinggi Ekonomi dan Bisnis Islam Darussalam (STEBIS) OKI SUMSEL \\ E-mail: tasurun@gmail.com
}

\begin{abstract}
Abstrak
Hasil penelitian menunjukkan bahwa pelaksanaan pembelajaran Pendidikan Agama Islam dilakukan dalam tiga tahap; perencanaan, implementasi dan evaluasi. Problematika yang ditemukan dalam penelitian ini adalah; kesulitan menghafal, tidak bisa membaca bahasa Arab, kurang minat belajar, kesulitan belajar, kreativitas guru dan siswa, pemilihan metode yang tidak sesuai, kurangnya media, perhatian orang tua dan masalah lingkungan. solusi yang dibuat oleh guru dan pengelola sekolah adalah; aspek siswa dengan meningkatkan motivasi, minat dan kemampuan belajar siswa dengan proses pembelajaran yang menarik. aspek guru dengan pembahasan Pendidikan Agama Islam, menyiapkan fasilitas pembelajaran dalam Pendidikan Agama Islam dengan baik, memberikan pelatihan kepada guru sesuai dengan kompetensi yang akan dikembangkan, serta pengawasan dan motivasi dari kepala sekolah. aspek pendekatan pembelajaran dengan memilih dan menggunakan metode dan media yang tepat. aspek lingkungan belajar siswa dengan membiasakan siswa dengan kegiatan keagamaan, menciptakan lingkungan keagamaan dan membangun semangat kompetisi dalam masalah agama..
\end{abstract}

Kata kunci: Problematika Proses Pembelajaran, Pendidikan Agama Islam

\section{PENDAHULUAN}

Pendidikan adalah kegiatan terencana, tersusun dan terarah menuju terbentuknya kematangan pribadi anak didik (Umar Tirtarahardja, 2010 : 34), sehingga menghasilkan insan-insan yang berkualitas baik dari segi sikap maupun intelektual serta bangsa yang bermartabat dan dijunjung tinggi oleh bangsa lain.

Dalam mencapai tujuan pendidikan secara optimal, proses pendidikan harus dilaksanakan dengan baik oleh segenap komponen pendidikan. Kualitas proses pendidikan dapat lihat dari dua kualitas aspek, yakni aspek komponen dan aspek pengelolaan, yang keduanya saling bergantung. Pada kenyataanya, ketika aspek komponen berkualitas baik namun tidak diimbangi dengan kualitas aspek pengelolaan yang baik maka pendidikan tidak akan mencapai tujuan secara maksimal, hal itu juga akan terjadi jika aspek pengelolaan berjalan dengan baik namun kualitas aspek komponen rendah. Dengan ini diharapkan seluruh aspek pelaku pendidikan dapat melaksanakan pendidikan dengan baik serta mampu dalam mengatasi segala problematika yang ada. Dalam pendidikan sekolah secara utuh, pembelajaran/proses belajar merupakan hal terpenting yang ada didalamnya. Ketuntasan tujuan pendidikan akan ditentukan oleh proses belajar tersebut (Slameto, $2010: 1$ ). Interaksi dalam proses belajar mengajar harus telah direncanakan secara sistematis demi tercapai tujuan pembelajaran Syiful Bahri Djamarah, Dkk. 2010 : 1). Dalam proses pembelajaran peran guru adalah sebagai informasi, sebagai organisasi, sebagai motivasi, sebagai director, sebagai pencetus ide, sebagai translator, sebagai fasilitator, sebagai mediator dan sebagai evaluator (Ngismatul Chairiyah, 2015). Anak didik menjadi penerima informasi, menyampaikan pendapat dan penyimpulkan hal yang baru.

Banyak penelitian mengatakan bahwa pendidikan di Indonesia sendiri telah mengalami peningkatan. Namun, kualitas tersebut belum bisa dikatakan maksimal melihat fenomena saat ini kondisi di lapangan yang terkadang menunjukkan lulusan-Iulusan kita belum mampu berkreasi aktif dalam bidangnya, rendahnya semangat dan produktifitas lulusan, sikap pasif yang terkesan menunggu lowongan pekerjaan. Dari sisi kepribadian, masih banyak mengalami kegagalan bahkan cenderung terjadi degradasi akhlak, seperti masih banyak terjadi siswa tidak lagi memiliki rasa hormat tehadap yang lebih tua termasuk orang tua dan guru, mengekspresikan perasaan lebih kepada halhal negatif seperti sex bebas, minum-minuman keras, merusak, sampai kepada bunuh diri. Fenomena inilah yang harus diamati dan dicarikan solusi oleh pengelola pendidikan termasuk juga pendidikan agama Islam didalamnya apalagi menyangkut kepribadian anak didik.

Pendidikan agama islam merupakan bagian dan pendukung terwujudnya tujuan pendidikan nasional yaitu aspek sikap dan keagamaan (iman dan takwa). Rumusan dalam mencapai tujuan tersebut berupa perhatian serta pengarahan anak didik agar dapat menggapai bahagia dunia dan akhirat. Guru mengarahkan anak didik untuk mempelajari, memahami serta mengimplementasikan apa yang sudaha menjadi ketentuan syariat agama islam (zakiyah daradjat, 2016 : 86). Secara 
khusus disebutkan fungsi dari pandidikan agama yaitu membina anak didik agar menjadi bagian dari salah satu komponen sosial yang paham dan mampu mengaplikasikan nilai-nilai Islam.

Problematika proses pembelajaran diantaranya :

1. Masalah guru, seorang guru pada dasarnya adalah manusia biasa yang dalam kehidupan sehariharinya tak luput dari masalah, baik masalah pribadi (keadaan jasmani, rohani dan profesionalisme guru), keluarga dan masyarakat, yang kemudian masalah tersebut terbawa dalam kegiatan pembelajaran. Terkait profesionalitas disini dimaksudkan guru yang biasanya hanya mengarahkan anak didik hanya kepada ranah kognitif dan minimya kreatifitas guru (Muslimin, 2017).

2. Masalah anak didik, baik masalah individu maupun prilaku/sikap yang membutuhkan perhatian guru selama proses pembelajaran.

3. Masalah lingkungan anak baik lingkungan sekolah, keluarga, ataupun lingkungan tempat bermain anak.

4. Masalah bahan atau materi pelajaran baik jumlah materi maupun ruang lingkupnya.

5. Masalah metode, metode Pendidikan Agama Islam yaitu; metode keteladanan, pembiasaan, ceramah, demontrasi tanya jawab, diskusi dan dan lain-lain

6. Masalah evaluasi, yaitu tehnik, jenis, pelaksanaan dan laporan penilaian hasil (Susiana, 2017).

Secara umum, masalah dalam proses belajar pendidikan agama Islam di sekolah sama dengan masalah secara umum, Heri menyebutkan antara lain (Heri G. 2017 : 259):

1. Masalah guru

Masalah yang dihadapi guru baik dalam keluarga, masyarakat, dan dalam pergaulan sosial yang terkadang terbawa dalam proses pembelajaran. Lebih lanjut, masalah pengalaman guru mengajar, kurangnya kemampuan guru dalam penguasaan bahan ajar dan keterampilan dalam dalam menggunakan metode-metode yang inovatif masih kurang, gaji guru yang rendah, minimnya komitmen guru, minimnya motivasi dari guru berpengaruh terhadap melaksanakan proses pembelajaran.

2. Masalah anak didik

Secara umum banyak dijumpai masalah-masalah yang sering muncul pada anak didik yang menghambat proses pembelajaran diantaranya masalah intelegensi, prilaku belajar, konsentrasi, menyimpulkan pelajaran, minim prestasi, kurang percaya diri, dan keberhasilan dalam belajar dan pandangan masa depan anak didik. Slameto $(2010$, h. 54) berpendapat masalah anak ada dua macam yaitu:

a. Masalah intern

Pertama, faktor jasmaniah yaitu keadaan fisik nank didik. Kedua, Faktor psikologis berisi tentang penalaran, keinginan, potensi, dan kesiapan. Ketiga, faktor kelelahan baik lelah fisik ataupun psikkis anak didik.

b. Masalah ekstern

Disebabkan oleh faktor keluarga mencangkup latar belakang pendidikan, ekonomi dan budaya keluarga. Faktor sekolah yaitu media dan metode, kurikulum, relasi, disiplin sekolah, sarana, waktu, kondisi fisik sekolah, dan tugas. Selanjutnya faktor masyarakat yaitu kegiatan siswa dalam kehidupan bermasyarakat, tehnologi dan teman bermain.

Selain itu juga faisal jalal (2001: 267) masalah keberagaman latar belakang anak didik dan kebutuhan belajar sehingga anak didik perlu mendapatkan perhatian yang sewajarnya dari sekolah.

3. Masalah lingkungan anak didik

Masalah dalam proses pembelajaran biasanya juga timbul dari lingkungan sekolah, keluarga, ataupun masyarakat sekitar anak didik. Lingkungan juga yang berpartisipasi membentuk pribadi anak didik sebagai individu yang utuh (zakiyah daradjad, 2016 : 100). Contoh kasus apabila masyarakat sekitar suka main togel, balap liar, minum-minuman keras, mengambil hak orang lain, suka keluar malam, berpendidikan rendah atau aktifitas-aktifitas negatif lainya, tentu pengaruh negatif tersebut akan terbawa dalam prilaku dan pikairan didik. Keinginannya untuk berprilaku sama dengan masyrakat tersebut menjadi penghambat belajar anak didik. Dari penjelasan tersebut, lingkungan yang kondusif dan baik perlu dibentuk untuk mendukung keberhasilan proses belajar anak didik. Disimpukan bahwa semakin baik lingkungan sekitar anak didik maka akan menjadikan pendukung bagi proses pelajar dan terpenuhi tujuan dari pembelajaran yang optimal.

4. Masalah bahan atau materi pelajaran

Masalah materi pelajaran antara lain: jumlah dan ruang lingkup materi. Pemberian materi dalam pembelajaran harus disesuaikan dengan kemampuan anak didik dan materi 
yang akan disampaikan memberika rasa ingin tahu serta menjadi suatu hal yang baru bagi anak didik. Guru sebaiknya menghindari pemberian materi yang diatas kemampuan anak didik, materi yang tidak dibutuhan atau tidak menjadi solusi bagi anak didik dan materi yang tidak efesien waktu.

5. Masalah metode mengajar

Metode merupakan cara atau strategi yang dipakaioleh guru atau pendidik dalam menyampaikan materi pelajaran kepada anak didik sehingga tujuan pembelajaran diharapkan dapat tercapai. Banyak pilihan metode yang tercantum dalam rencana pembelajaran, namun dalam implementasinya terkadang metode yang direncanakan tidak maksimal.

6. Masalah evaluasi

Evaluasi berfungsi sebagai alat ukur apakah suatu pembelajaran telah tercapi dengan baik atau belum. Evaluasi dianggap baik adalah telah mencangkup beberapa prinsip (Anas Sudijono, 2011, h. 31-33):

a. Prinsip keseluruhan (comprehensive), evaluasi dikatan baik apabiala mampu mengevaluasi objek secara utuh.

b. Prinsip kesinambungan (continuity), maksudnya evaluasi atau penilaian harus dilakukan secara terncana, terus menerus dan terjadwal. Dengan prinsip ini hasil belajar anak didik dari awal hingga akhir proses pembelajaran dapat dipantau oleh guru.

c. Prinsip objektivitas (obyektivity), yaitu evaluasi yang sebenarnya, sesuai dengan fakta yang terjadi dan tidak dipengaruhi oleh kepentingan-kepentingan yang subjektif.

Proses evaluasi terjadi saat ini belum sempurna dilakukan oleh guru. Adakalanya guru mengevaluasi salah satu aspek penilaian saja, malas membuat instrumen penilaian sikap dan ketrampilan, dan terbatasnya waktu evaluasi. Hasil evaluasi yang hanya kognitif itu dijadikan hasil akhir belajar anak didik, maka akan terjadi penilaian yang kurang obyektif. Adakalanya anak didik yang memiliki akhlak baik, disiplin dan rajin beribadah lebih rendah nilainya daripada anak didik kuang baik kepribadianya. Yang harus dilakukan adalah melaksanakan evaluasi sesuai dengan ketentuan-ketentuan yang ada, objektv dan menyeluruh.

\section{METODE/EKSPERIMEN}

Penelitian ini berupaya untuk mendeskripsikan proses pembelajaran pendidikan agama Islam, problematika dan upaya penanggulangannya, di SMPN 3 Trenggalek dan SMPN 1 Bendungan. dengan cara pendekatan kualitatif, berupa penelitian eksplorasi serta paham terhadap masalah sosial atau objek yang diteliti secara alamiah (Jhon W. Creswell, $2010: 4$ ). Studi kasus sebagai rancangan penelitian dengan mendeskripsikan masalah, baik latar maupun objek yang diteliti secara menyeluruh, rinci dan mendalam. Studi kasus merupakan rancangan penelitian dengan tujuan memahami dan mendeskripsikan keadaan sosial meliputi individu dan kelompok, lembaga dan masyarakat (Yatim Riyanto, $2001: 24$ ).

Penelitian dengan pendekatan kualitatif mengharuskan peneliti sebagai instrumen utamanya (Sugiono, 2008 : 223). Maka, peneliti akan secara langsung terjun ke lapangan, sebagai pencari data, redaksi, analisator dan penentu konklusi dari masalah yang diteliti. Latar dalam penelitian ini yaitu SMPN 3 Trenggalek dan SMPN 1 Bendungan. Kedua sekolah tersebut meiliki perbedaan secara geografis yaitu SMPN 3 Trenggalek berada di tengah linkungan perkotaaan dan SMPN1 Bendungan terletak di pedesaan. Perbedaan kondisi sekolah tersebut diambil untuk mengoptimalkan penelitian kaitanya tentang problematika pendidikan agama Islam. Informan sebagai sumber data yaitu kepala sekolah, guru, civitas sekolah dan anak didik, juga sumber skunder diataranya masyarakat sekitar sekolah, orang tua anak didik dan data fisik lainya.

Teknik pengumpulan data dilakukan dengan observasi berperan serta (participan obsevation), wawancara mendalam (in depth interview), teknik dokumentasi dan triangulasi. kemudian dianalisis dengan teknik sebagai berikut; pertama, analisis data tunggal (reduksi data, penyajian dan penarikan kesimpulan). Dilanjutkan analisis kedua, analisis lintas situs (merumuskan proposisi, membandingkan dan menarik simpulan). Ketiga, penyajian data (data display). Keempat, merupakan tahap terakhir penelitian ini berupa pengambilan kesimpulan (conclusion drawing) dan verifikasi. Dengan analisis tersebut dapat dihasilkan kesimpulan yang nantinya akan menjadi temuan baru dalam penelitian ini. 


\section{HASIL DAN PEMBAHASAN}

\section{A. Pelaksanaan Proses Pembelajaran Pendidikan Agama Islam (PAI)}

Pembelajaran merupakan suatu aktifitas yang didalamnya terkandung dua kegiatan sekaligus, yakni kegiatan yang anak didik sebagai pelajar dengan guru sebagai pengajar yang sedang mengajar (Muhibbin Syah, 2008, h. 237). Pelaksanaan peracanaan pembelajaran oleh guru Pendidikan Agama Islam (PAI) di SMP 3 Trenggalek dan SMPN 1 Bendungan diwujudkan dalam bentuk program tahunan, program semester, silabus dan RPP yang telah disetujui oleh kepala sekolah.Silabus dan RPP yang ada di SMP 3 Trenggalek dan SMPN 1 Bendungan masing-masing telah dikembangkan sesuai dengan kondisi sekolah, anak didik, materi dan kebutuhan masyarakat. Beberapa pertimbangan dalam pengembangan perangkat perencanaan pembelajaran PAI yang dilakukan oleh guru lebih luas dijelaskan sebagai berikut:

1. Keadaan sekolah

Perumusan rencana pelaksanaan pembelajaran oleh guru harus disesuaikan dengan kondisi sekolah, dengan cara mengetahui apasaja sarana prasarana yang siap pakai di sekolah, media yang tersedia atau yang sudah rencanakan pengadaannya dan inventaris bahan ajar yang tersedia di sekolah dalam kaitanya dengan pelajaran pendidikan agama Islam.

2. Kondisi anak didik

Penyusunan perangkat pembelajaran tentunya harus mempertimbangkan kondisi anak didik. Seorang guru tentu telah memahami keadaan siswa dan karakteristik siswa dalam masingmasing kelas. Hal ini berpengaruh terhadap metode dan strategi yang akan dilaksanakan dalam pembelajaran.

3. Materi

Selain kemampuan siswa, materi yang diajarkan oleh siswa juga menjadi pertimbangan dalam menyusun RPP. Melihat luasnya ruang lingkup materi ajar PAI di sekolah meliputi tujuh pokok yaitu keimanan, ibadah, Al-Qur'an, akhlak, muamalah dan tarikh, serta ada materi yang dikategorikan materi sulit, sedang, ataupun mudah. Maka materi pendidikan agama Islam harus teridentifikasi, mana mmteri-materi yang prinsip (dasar), real (fakta), konsep (ide/pemikiran), prosedur, atau materi yang mencangkup berbagai jenis materi. Identifikasi materi berguna bagi seorang guru untuk memilih strategi, metode, media, menentukkan alokasi waktu pembelajaran nantinya, serta menentukan teknik evaluasi yang akan digunakan. Kebutuhan masyarakat

Pertimbangan atas kebutuhan masyarakat menjadi penting, melihat masyarakat adalah tempat dimana anak didik secara langsung bisa mengimplementasikan pengetahuannya dan dapat menjadi atau memberi solusi bagi masalah keagamaan yang ada. Pertimbangan atas kebutuhan masyarakat perlu dilakukan juga sebagai penunjang tercapainya tujuan Pendidikan Agama Islam untuk menumbuhkan nilai-nilai Islam di tengah masyarakat (Abdul Madjid, 2012 : 15). guna tercapainya hal tersebut, guru melakukan pengamatan kondisi masyarakat khusunya di sekitar sekolah, apa yang menjadi kebutuhan masyarakat tersebut dan guru memberikan upaya-upaya edukatif agar anak didik siap dan mampu berpartisipasi secara aktif menjadi jalan keluar atau solusi bagi kebutuhankebutuhan masyarakat yang ditemukan.

Pelaksanaan pembelajaran di SMPN 3 Trenggalek dan SMPN 1 Bendungan dilaksanakan dengan beberapa tahapan, yaitu tahapan pendahuluan, inti dan penutup.

1. Pendahuluan

Tahap pendahuluan biasanya guru mengkondisikan anak didik baik jasmani dan rohani agar siap belajar, melakukan appersepsi, guru memaparkan tujuan-tujuan yang ingin dicapai dalam pembelajaran, guru memberikan materi pelajaran dan menjelaskan sistematika kegiatan 2. Inti belajar sesuai dengan perangkat pembelajaran yang telah disiapkan.

Kegiatan tahapan inti disini dilakukan tiga kegiatan, yaitu eksplorasi (penjajakan), elaborasi (paparan) dan konfirmasi (penegasan/pembuktian). Eksplorasi, didalamnya guru dan anak didik mencari informasi tentang materi yang sedang dipelajari, variasi guru dalam pendekatan pembelajaran, guru sebagai fasilitator dalam interaksi seluruh komponen kelas dan memberikan kesempatan sepenuhnya kepada anak didik untuk berpartisipasi aktif dalam belajar. Dalam tahap ini juga dianjurkan kepada guru untuk memfasilitasi anak didik dalam melakukan percobaan di laboratorium, studio dan lapangan (Abdul Madjid, 2012 : 123). Namun dalam kenyataannya dalam pembelajaran PAI yang terlaksana kegiatan ini belum ditemui. Tahap kedua, elaborasi kegiatan yang dilaksanakan guru membiasaka anak didik membaca dan menulis, pemberian tugas, memberikan kesempatan anak didik agar berfikir, menalar dan menghayati, mencari problem solving, menyimpulkan dan menunjukan hasil kerja dalam bentuk laporan. Selain itu, dalam pengamatan menunjukan bahwa upaya guru secara teori yang belum 
terlaksana dalam pembelajaran yaitu guru memberikan fasilitas bagi anak didik muntuk mengekspos dan mendemontrasikan karya atau produk hasil dari pembelajaran yang dapat meningkatkan rasa percaya diri dan bangga pada anak didik (Abdul Madjid, 2012 : 124). Tahap ketiga, konfirmasi yang merupakan tahap dimana guru memberikan pemantapan pengertian dan pemahaman informasi/materi yang telah dibahas. Kegiatan yang dilaksanakan berupa tanya jawab, anak didik menjelaskan kembali materi, mengimplementasikan materi dan evaluasi kegiatan pembelajaran.

3. Penutup

Dalam kegiatan penutup dalam proses pembelajaran yang dilakukan oleh guru adalah menyimpulkan materi, memrefleksi kegiatan pembelajaran yang telah berlangsung dan memberikan tugas atau penilaian terhadap anak didik.

B. Problematika Proses Pembelajaran Pendidikan Agama Islam

Problematika pembelajaran pendidikan agama Islam yang ada di SMPN 3 Trenggalek lebih banyak daripada problematika yang ada di SMPN 1 Bendungan. Perbedaan problematika tersebut dimunkingkan terjadi mengingat kondisi dan keberadaan masing-masing sekolah yang berbeda. Problematika-problematika yang dapat diidentifikasi diantaranya :

1. Anak didik

Problematika anak didik adalah segala sesuatu yang dianggap menyulitkan dan melambankan dalam belajar (Susiana, 2017). Problematika yang sering dihadapi oleh anak didik yaitu kesulitan menghafal, tidak bisa baca arab, minimnya mativasi belajar dan kesulitan memahami materi pendidikan agama Islam yang diajarkan. Beberapa faktor yang menyebabkan hal tersebut adalah :

a. Faktor intern, yaitu perbedaan intelgensi, minimnya minat dan bakat anak didik terhadap pelajaran pendidikan agama Islam. Dalam proses belajar mengajar, anak didik memiliki perbedaan dalam kecepatan menyerap materi serta memahaminya dan yang berkaitan dengan kurangnya minat dapat disebabkan oleh tidak adanya daya tarik bagi anak didik, tidak menemukan kepuasan belajar dan tidak menjadi solusi bagi anak didik.

b. Faktor ekstern, problematika anak didik dalam pembelajaran bisa timbul karna budaya menghafal dalam pembelajaran telah sedikit ditinggalkan, latar belakang pendidikan anak didik serta faktor keluarga. Keluarga merupakan institusi sosial yang bersifat universal multifungsional, yang memiliki fungsi pengawasan, sosial, pendidikan, keagamaan, perlindungan dan rekreasi (Moh. Padil, 2007 : 117). Masalah faktor keluarga diantaranya; bagaimana cara orang tua mendidik, relasi antara keluarga, iklim di dalam rumah, status sosial ekonomi keluarga, keluarga sebagai motivator dan kebiasaan yang ada dalam keluarga. Maka, apabila keluarga kurang atau bahkan tidak memberikan perhatian tentang pendidikan agama, juga minimnya motivasi serta tidak adanya teladan yang baik, hal tersebut dapat berpengaruh terhadap minat dan semangat belajar anak didik di sekolah. Sebaliknya, apabila lingkungan anak didik memberikan perhatian dan teladan yang baik maka akan berpengaruh positif bagi keberhasilan pembelajaran PAI pada anak. Yang harus diperhatikan dalam pembelajaran anak didik adalah guru dalam proses belajar harus mempertimbangkan sikap, kepercayaan, dan aspirasi sebagai bagian yang integral dalam lingkungan belajar, karna kesiapan belajar siswa dipengaruhi oleh 2. Guru kekuatan-kekuatan kultural dalam lingkungannya (Oemar Hamalik, 2014 : 63).

Masalah guru yang ditemukan dalam proses pembelajaran yaitu; guru kurang berkreativitas dan minimnya upaya guru dalam mengembangkan prestasi anak didik menjadi masalah yang dihadapi oleh guru.

Kreatifitas guru menjadi masalah ketika kondisi sarana prasarana yang telah tersedia dengan baik, tekhnologi dan perkembangan sosial masyarakat dilingkungan sekolah yang lebih maju namun tidak memberikan manfaat bagi proses pembelajaran. Oleh karna itu, guru dituntut mampu mengembangkan diri untuk lebih kreatif dalam melihat potensi yang ada disekolah, dalam hal ini Munjin Nasih berpendapat ada dua hal yang harus diperhatikan oleh guru dalam pembelajaran. Pertama, guru hendaknya mengetahui fasilitas apa saja yang tersedia disekolahnya serta bagaimana memperoleh dan menggunakannya. Kedua, guru yang tidak cakap dalam menggunakan fasilitas tertentu atau tidak mampu menerapkan pada metode yang sesuai, meskipun fasilitas itu memadai, akan terganggu dengan fasilitas tersebut (Ahmad. M. Nasih, 2013 : 45). Sehingga guru diharapkan cakap dan kreatif dalam memanfaatkan faslitas yang ada.

Selanjutnya mengenai minimnya upaya guru dalam memberikan motivasi disini dibuktikan dengn sedikit sekali penghargaan dalam bidang agama Islam, sulit menemukan 
siswa yang memiliki potensi terhadap pendidikan agama Islam, jarang mengikuti kegiatan keagamaan di luar sekolah dan kurang terkoordinirnya kegiatan tambahan bidang keagamaan di sekolah. dapat menciptakan proses pembelajaran atau program-program keagamaan di sekolah yang mampu memotivasi anak didik untuk berprestasi dan memberikan kebanggan bagi sekolah. Guru sebagai problem solver harus mampu mengatasi masalah-masalah tersebut sehingga anak didik lebih termotivasi dan berprestasi.

3. Metode

Metode bagi guru bermanfaat untuk menciptakan suasana belajar dan merancang kegiatan guru dan anak didik ketika proses belajar mengajar berlangsung (Abdul Madjid, 2012 : 132). Pemilihan metode dalam belajar yang tepat adalah metode yang menghasilkan cara belajar yang tepat dan efektif, pemberian waktu belajar yang cukup dan mendapatkan hasil belajar yang baik. Metode yang dipakai dalam pembelajaran pendidikan agama Islam di SMPN 3 Trenggalek dan SMPN 1 Bendungan sangat berfariasi. Pada kenyataannya saat pelaksanaan pembelajaran pemilihan metode yang direncanakan tidak sesuai dengan kondisi kelas atau anak didik, contoh ketika kondisi siswa sudah lelah belajar maka metode demonstrasi tidak akan efektif. Akhirnya anak didik tidak bersungguhsungguh dalam belajar ada yang tidur, ngobrol atau keluar dari kelas. Dalam menghadapi hal ini guru harus siap mencarikan solusi dengan memilih dan menggunakan metode yang lain yang lebih sesuai dengan kondisi anak didik tujuan serta materi yang disampaikan, karna tujuan dan materi yang baik belum tentu memberikan hasil yang baik tanpa memilih metode yang yang sesuai dengan tujuan dan materi tersebut.

4. Media

Minimya media yang tersedia dalam pembelajaran baik visual, audio maupun audio visual pada SMPN 1 Bendungan menjadi masalah yang harus dihadapi.beberapa media yang sering dipakai adalah masjid, Al-Qur'an, iqro' dan buku agama. Selain itu mediamedia baik visual, audio maupun audio visual belum digunakan dalam pembelajaran. Melihat media yang ada disekolah, guru juga harus kreatif dalam memilih media yang relevan terhadap materi yang diajarkan dan dapat mempermudah anak didik dalam membangangun pengetahuanya.Hal ini juga dikemukakan oleh lif Khoiru Ahmadi (2011: 167) yang menjadi malasalah dalam pemilihan media yakni tidak relevan pemilihan media, disebabkan oleh waktu yang terbatas, kompetensib guru yang belum memadai dalam pengoprasian media yang digunakan.

Media dalam pembelajaran begitu penting, media dapat meningkatkan efesiensi dan efektifitas proses dan kualitas hasil belajar. Selain itu, media dalam prooses belajar mengajar bisa menjadi alternatif solusi bagi masalah-masalah yang ada, Oemar hamalik (2014 : 65) menyebutkan beberapa manfaat media dalam proses pembelajaran, yaitu :

a. Verbalisme,

b. Kekacauan penafsiran,

c. Perhatian anak didik yang bercabang,

d. Kurangnya respon anak didik,

e. Kurang perhatian, dan

5. Lingkungan

f. Keadaan fisik lingkungan belajar.

Menurut Moh. Padil (2007: 82) lingkungan adalah keadaan extern dari individu yang berpengaruh terhadap perkembangan seorang anak. Apalagi lingkungan keluarga, beberapa faktor berpengaruh terhadap anak didik diantaranya; kultur keluarga, pendidikan orang tua, keadaan ekonomi, karir orang tua, cara orang tua menyelesaikan masalah sekitar dan kehidupan masyarakat yang sebenarnya. yang kadang terjadi orang tua kurang memperhatikan waktu belajar anak dirumah, akhirnya motivasi belajar untuk anak sangat minim. Selain itu kurangnya perhatian terhadap anak didik untuk mengikuti kegiatan keagamaan, seperti mengaji atau mengikuti kegiatan yang ada di masjid. Dalam lingkup sekolah, ada juga anak yang keluar dan jajan di kantin saat pembelajaran berlangsung.

C. Upaya Mengatasi Problematika Pembelajaran Pendidikan Agama Islam (PAI)

Dalam mengatasi problematika pembelajaran yang ada, guru dan pihak pengelola sekolah di SMPN 3 Trenggalek dan SMPN 1 Bendungan telah melakukan beberapa upaya dalam mengatatasi problematika tersebut, upaya dalam mengatasi problematika pada anak didik, guru, media, metode dan problematika lingkungan. 
upaya-upaya yang dilakukan dalam mengatasi problematika proses pembelajaran PAI, yaitu :

1. Anak didik

Problematika pembelajaran Pendidikan Agama Islam terkait anak didik, upaya guru adalah; membiasakan anak didik membaca Al-Qur'an dengan program baca-tulis Al-Qur'an, menciptakan suasana yang santai danmenyenangkan dalam menghafal dengan cara me"lagu"kan dan melalui menggambar materi hafalan. Upaya-upaya ini dilakukan guru untuk melatih anak didik agar kesulitan menghafal dan tidak bisa baca arab dapat teratasi dengan baik.

Terkait dengan problem minimnya minat dan motivasi anak didik dalam belajar pendidikan agama Islam, Upaya berikan oleh guru yaitu membentuk iklim belajar yang baik, menarik serta menyenangkan, upaya ini dilakukan dengan cara guru memakai metode dan media pembelajaran yang tidak monoton, belajar lapangan, anak didik diberikan kesempatan untuk mempraktikkan materi yang diajarkan dan guru memberikan informasi materi yang menarik dan memilih penjelasan yang berkaitan langsung terhadap anak didik dalam kehidupan sehari-hari srta keinginan atau cita-cita masa depan anak didik. tujuan upaya tersebut adalah adanya kecendrungan anak didik yang kontinue, perasaan penting, senang dan bangga untuk belajar pendidikan agama Islam.

2. Guru

Problematika pada guru menyangkut kreatifitas dan kurangnya semangat guru dalam memberikan pengarahan untuk anak didik agar terus meningkatkan prestasi. Upaya pengelola sekolah dalam hal ini meliputi; diskusi Pendidikan Agama Islam yang aktif dan terjadwal, sharing guru, menyediakan sarana-prasarana pembelajaran Pendidikan Agama Islam dengan maksimal, membuka atau mengarahkan guru untuk mengikuti pelatihanpelatihan sesuai dengan kompetensi yang ingin dikembangkan, dan pengawasan serta motivasi dari kepala sekolah. Akhirnya seorang guru dihapkan sesuai dengan syarat seorang guru yang diantaranya memiliki profesionalitas yang tinngi, mampu mgamalkan nilai-nilai islam danmemberikan teladan yang baik bagi anak didik (Muslimin, 2017).

3. Pendekatan Belajar

Problematika pembelajaran PAI diataranya adalah media dan metode pembelajaran, hal inilah yang termasuk upaya pada pendekatan pembelajaran. Menurut muhibbin syah (2008 : 136), pendekatan pembelajaran merupakan keefektifan segala cara atau strategi yang digunakan dalam menunjang aktivitas dan efesiaensi proses pembelajaran tertentu. Lebih lanjut ia menyebutan pendekatan pembelajaran merupakan pengembangan atau kreasi baru dalam bentuk metode, strategi, bahan dan penataan lingkungan yang lebih baik. Upaya-upaya yang dilakukan guru dalam mengatasi problematika proses pembelajaran PAI yaitu pemilihan metode yang sesuai materi, anak didik dan sekolah, pengadaan media pembelajaran yang dibutuhkan.

4. Lingkungan

Problematika lingkungan didalamnya termasuk kreatifitas seorang guru, artinya guru sebagai salah satu komponen yang ada dalam lingkungan sosial anak didik berpengaruh terhadap kegiatan belajar anak didik. Upaya yang dilakukan pengelola sekolah yaitu membina guru-guru agar kreatif melalui diskusi agama, menyediakan sarana-prasarana yang diperlukan, membuka atau mengikutsertakan guru dalam pelatihan atau seminar yang sesuai dengan kompetensi.

Selanjutnya dalam menciptakan lingkungan yang baik, upaya yang dilakukan adalah mengadakan program keagamaan seprti sholat duhur, hafalan surat pendek, dan kultum. Guru juga mengadakan kegiatan peringatan hari besar Islam, memberikan kelompok belajar dan mengikutsertakan anakdidik dalam kegiatan keagamaan yang ada di luar sekolah.

Dengan beberapa alternatif upaya yang dilakukan pengelola sekolah diharapkan mampu mengatasi problem-problem yang muncul, akhirnya pembelajaran pendidikan agama islam (PAI) dapat dilaksanakan dengan baik, dapat memberikan semangat dan minat belajar anak didik dan terwujud lingkungan yang kondusif mampu medukung proses belajar. Apabila hal ini telah tercapai maka bukan tidak mugkin pembelajaran PAI akan mudah mencapai tujuan pembelajaran yang telah ditentukan.

\section{PENUTUP}

Pembelajaran Pendidikan Agama Islam (PAI) di SMP 3 Trenggalek dan SMPN 1 Bendungan 
dilakukan melalui tiga bentuk tahapan yaitu perencanaan (palnning), pelaksanaan (implementation) dan penilaian (evaluation). Pelaksanaan planning pembelajaran dirumuskan dalam bentuk program tahunan (prota), program semester (promes), silabus dan Rencana Pelaksanaan Pembelajaran (RPP) dengan persetujuan kepala sekolah. Perangkat terssebut kemudian disesuaikan dengan kondisi anak didik, intern dan extern sekolah, kebutuhan materi dan kebutuhan publik sekitar sekolah. Pelaksanaan pembelajaran di SMPN 3 Trenggalek dan SMPN 1 Bendungan diimplementasikan melalui tiga tahapan, yaitu tahap pendahuluan, inti dan penutup. Tahapan pendahuluan, guru mengkondisikan anak didik secara jasmani dan rohani agar siap belajar, kegiatan appersepsi, menjelaskan tujuan-tujuan belajar yang ingin dicapai. Tahapan inti yaitu kegiatan belajar. Tahapan akhir yaitu penutup, dalam proses pembelajaran yang dilakukan oleh guru adalah menyimpulkan materi, memrefleksi kegiatan pembelajaran yang telah berlangsung dan memberikan tugas atau penilaian terhadap anak didik.

Problematika pembelajaran PAI yang ditemukan di SMPN perkotaan lebih banyak ditemui dibandingkan dengan problematika pada SMPN pedesaan. Meliputi Problematika yang dihadapi oleh anak didik yaitu kesulitan menghafal, tidak bisa baca arab, minimnya semangat belajar dan kesulitan memahami pelajaran. Kurangnya kreativitas guru dan minimnya upaya guru dalam mengembangkan prestasi anak didik menjadi masalah yang harus dihadapi oleh guru, pemilihan metode tersebut dirasa kurang tepat dilihat dari kondisi siswa, Minimya media yang tersedia dalam pembelajaran baik visual, audio maupun audio visual, orang tua kurang memperhatikan waktu belajar anak di rumah, akhirnya motivasi belajar untuk anak sangat minim. Selain itu kurangnya perhatian terhadap anak didik untuk mengikuti kegiatan keagamaan, seperti mengaji atau mengikuti kegiatan yang ada di masjid.

Upaya yang dilakukan oleh guru dan pihak sekolah di SMPN 3 Trenggalek dan SMPN 1 Bendungan mengatasi problematika anak didik yaitu penekanan hafalan, hafalan dengan lagu, membudayakan anak didik untuk membaca dan menulis Al-Qur'an, program baca-tulis Al-Qur'an serta menciptakan suasana belajar yang kondusif menyenangkan. Selanujtnya, kreativitas guru dapat dikembangkan melalui beberapa kegiatan meliputi diskusi pendidikan agama Islam, Menyiapkan sarana dan prasarana yang dibutuhkan, memberikan atau mengikutsertakan guru dalam pelatihanpelatihan atau seminar sesuai dengan kompetisi yang dibutuhkan. Untuk metode pembelajaran guru mengupayakan pemilihan metode sesuai materi, kondisi anak didik dansekolah. Pengadaan media yang dibutuhkan dan pemilihan media secara tepat menjadi solusi dalam problematika media pembelajaran. Upaya-upaya yang dilakuan dalam mengatasi problamatika lingkungan meliputi program keagamaan (sholat duhur, hafalan surat pendek dan kultum), Peringatan hari besar Islam, kelompok belajar dan mengikut sertakanan anak didik dalam kegiatan agama di luar sekolah.

\section{UCAPAN TERIMAKASIH}

Peneliti mengucapkan terimakasih kepada Sekolah Tinggi Ekonomi Dan Bisnis Islam Darussalam Lempuing OKI, LPPM STKIP Nurul Huda Sukaraja OKU Timur Dan Tim Jurnal AI I'tibar Program Studi Pendidikan Agama Islam STKIP Nurul Huda.

\section{DAFTAR PUSTAKA}

Ahmadi, lif Khoiru. Dkk. 2011. Strategi Pembelajaran Sekolah Terpadu. Jakarta: Prestasi Putakarya. Budihardjo, Eko. 2000. Problematika Pendidikan Agama Islam. Yogyakarta, pustaka pelajar.

Creswell, Jhon W. 2010. Research Design Pendekatan Kualitatif, Kuantitatif, Dan Mixed. Yogyakarta: Pustaka Pelajar.

Daradjad, Zakiyah. 2006. IImu Pendidikan Islam. Jakarta : Bumi Aksara.

2001. Metodologi Pengajaran Agama Islam. Jakarta : Bumi Aksara.

Gunawan, Heri. 2013. Kurikulum Dan Pembelajaran Pendidikan Agama Islam. Bandung: Alfabeta.

Hamalik, Oemar. 2014. Psikologi Belajar Dan Mengajar. Bandung: Sinar Baru Aglesindo.

2008. Himpunan Perundang-Undangan Republik Indonesia Tentang System Pendidikan National. Bandung: Nuansa Aulia. 
Jalal, Fasli. dkk. 2001. Reformasi Pendidikan Dalam Konteks Otonomi Daerah. Yogyakarta: PT Mitra Gama Widya.

Majid, Abdul. 2012. Belajar Dan Pembelajaran Pendidikan Agama Islam. Bandung: PT Remaja Rosda Karya.

2006. Pendidikan Agama Islam Berbasis Kompetensi. Bandung PT Remaja Rosdakarya.

M. Yunus Abu Bakar, "Problematika Pendidikan Islam Indonesia" Dirasat, Jurnal manajemen Dan Pendidikan Islam, Vol. 1 No. 1 (Juli-Desember 2015)

Muslimin, "Problematika Pembelajaran Pendidikan Agama Islam Dan Upaya Solusi Guru Dalam Pembinaanya Di Sekolah." Jurnal IImiah Pendidikan Vol. 01, No. 2 (Desember 20017)

Nasih, A. Munjin. Dkk. 2013. Metode Dan Teknik Pembelajaran Pendidikan Agama Islam. Bandung: PT Redika Aditama.

Ngismatul Chairiyah, "Problematika Pembelajaran Pendidikan Agama Islam Di SD." Jurnal Rohima Vol. 02. No. 1 (Desember 2015).

Riyanto, Yatim. 2001. Metodologi Penelitian Pendidikan, Surabaya : SIC.

Sugiyono. 2008. Metode Penelitian Kuantitatif, Kualitatif Dan R\&D. Bandung: Alfabeta.

Sudijono, Anas. 2011. Pengantar Evaluasi Pendidikan, Jakarta: Rajawali Pers.

Susiana, "Problematika Pembelajaran Pendidikan Agama Islam DI SMKN 1 Turen" Jurnal At-Tariqoh Vol. 2 No. 1 (Juni 2017).

Syah, Muhibbin. 2008. Psikologi Pendidikan dengan Pendekatan Baru, Edisi Revisi. Bandung: PT Remaja Rosdakarya.

Tirtarahardja,Umar. 2010. Pengantar Pedidikan. Jakarta: PT. Rineka Cipta.

Undang-Undang Sistem Pendidikan Nasional. 2003. Yogyakarta : Media Wacana. 